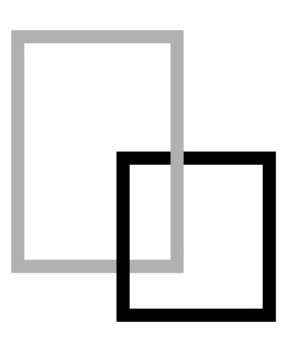

\title{
NIE0CZYWISTA ROLA RUIN POPRZEMYSŁOWYCH W KRAJOBRAZIE KULTUROWYM POLSKI
}

Ambiguous role of post-industrial ruins in the cultural landscape of Poland

\section{Jacek Dąbrowski*, Bartosz M. Walczak**}

SUMMARY: The paper deals with the issues related to protection of industrial heritage. Authors focused on the problem of derelict industrial objects in the state of disrepair, which might be considered as historic ruins. The discussed subject was settled in the historical and socio-cultural context. The importance of perception and identity was underlined as crucial factors for successful heritage protection, including former industrial sites. This is followed by the critical analysis of selected cases of ruined factories.
Various approaches to the post-industrial ruins ware identified. The location type as well as local society approach to the industrial pasts were identified as the most important aspects determining adopted heritage protection scenarios. The role of contemporary pop- and digital cultures was also identified in respect of experience authenticity.

KEYWORDS: industrial archaeology, ruins, industrial heritage protection

\section{Wstęp}

Jako datę uznania obiektów i urządzeń przemysłowych za element dziedzictwa kulturowego przyjmuje się rok 1963, kiedy to ukazała się publikacja Kennetha Hudsona - „Industrial Archaeology". Po raz pierwszy zdefiniowane zostało pojęcie „archeologia przemysłowa”. Zainteresowanie zabytkami przemysłowymi jest jednak zdecydowanie wcześniejsze ${ }^{2}$. W Polsce, już w 1951 r. Feliks Kanclerz pisał o „ochronie zabytków budownictwa przemysłowego” ${ }^{3}$. Pomimo podtekstu ideologicznego i upływu prawie 70 lat, poglądy zaprezentowane w tym tekście są zadziwiająco aktualne. Stąd dłuższy cytat:

„Takie zabytki kultury materialnej [zabytki przemysłowe - przyp. Autorzy] spotykamy w muzeach archeologicznych, etnograficznych i nielicznych technicznych, gdziejako eksponatyzłożone sa wśród przedmiotów innego rodzaju w gablocie lub hali w oderwaniu od zespołu wytwórczego, takiego jak warsztat rzemieślniczy czy zakład przemysłowy. Zabytek $w$ takich warunkach ekspozycji jest mało przekonywujący, natomiast będzie nam więcej mówił o produkcji i o człowieku

\footnotetext{
* MSc of archeolgy Jacek Dąbrowski, Monuments Preservation Department, The Ministry of Culture and National Heritage https://orcid.org/0000-0002-2146-976X,

** Prof Arch Bartosz M. Walczak, Institute of Architecture and Urban Planning, Łódź University of Technology https://orcid.org/0000-0002-9429-9626

1 K. Hudson, Industrial Archaeology: An Introduction, London - New York 1963.

2 Por. B.M. Walczak, Czy zabytki techniki i inżynierii to w Polsce wciąż dziedzictwo „drugiej kategorii”? Rys historyczny oraz aktualne problemy [w:] „Ochrona dziedzictwa kulturowego”, nr 2: 2016, s. 133-144.
}

3 F. Kanclerz, Ochrona zabytków budownictwa przemysłowego, „Ochrona zabytków”, nr 4: 1951, s. 113-118. 
w niq wprzęgniętym, gdy go ukażemy w całym zespole faktów, które warunkowały jego istnienie. Szczególniej odnosi się to do zabytków środków produkcji związanych z obiektem nieruchomym dziełem górniczym, czy budowlanym, czyli zabytków budownictwa przemysłowego.

Zabytkiem budownictwa przemysłowego jest bowiem budynek z urzadzeniem mechanicznym do produkcji a także dzieło inżynierskie przetwarzajace energie przyrody (np. wody, wiatru, zwierzat) w energię mechaniczna, wzniesione i urządzone w epoce minionej"'.

Feliks Kanclerz postulował - ni mniej, ni więcej - ochronę zabytków in situ. Czyli najlepszą z możliwych, bo dającą możność prowadzenia najbardziej skutecznych działań o charakterze edukacyjnym.

Nader ważna $\mathrm{w}$ procesie ochrony zabytków przemysłu będzie, przywołana wcześniej, „archeologia przemysłowa” rozumiana jako zbiór narzędzi do prowadzenia usystematyzowanych badań terenowych (na podobieństwo do „klasycznej” archeologii). Bowiem dla archeologii przemysłowej, podobnie do tradycyjnej, równie ważne jest ustalanie i identyfikacja „warstw kulturowych", zwiazanych z procesami przeobrażen dzieł przemysłu i techniki oraz przemian $w$ sferze społecznej $i$ kultury. Zakłady przemysłowe rozwijały się $w$ ciagu dziesiatek lat, zmienialy się i modernizowaty, czasami procesy te zachodzity nawet w perspektywach stuleci. Wielość nawarstwień właściwa tym kompleksom i ich technicznemu wyposażeniu, zmienna infrastruktura i ekosystem wymagają rozróżnienia i identyfikacji przedmiotów i środowiska w czasie ${ }^{5}$.

\section{Geneza zjawiska}

Rozwój społeczno-gospodarczy i towarzyszący mu niezmiernie dynamiczny postęp technologiczny jest jednym $\mathrm{z}$ najważniejszych czynników deindustrializacji. Rozumianej jako odejście od "klasycznego" przemysłu kojarzonego z licznymi, wielkimi, ciężkimi halami, dymiącymi kominami - takim nieco „księżycowym krajobrazem” dawnego przemysłu.

Zjawisko to ma charakter powszechny - dzisiejsza wytwórczość, kojarzona jeszcze tak niedawno z brudem, zapyleniem, dymami, smarami itp., ma „jednoznacznie czysty” charakter. Np. wymagająca dawniej wielkich przestrzeni i niezmiernie uciążliwa dla otoczenia budowa wielkich statków [kontenerowców, wycieczkowców, gazowców itp.] czy okrętów wojennych, jest dziś realizowana w ogromnych, „czystych” halach ${ }^{6}$. Najważniejszą cechą dzisiejszego procesu produkcyjnego jest logistyka, rozumiana jako zsynchronizowana co do minuty dostawa na „współczesny plac budowy”, każdego elementu składowego.

Tak rozumiany i realizowany proces wytwórczy wymaga wysoko wykwalifikowanej kadry inżynierskiej i robotniczej, ale co za tym idzie, o wiele mniej licznej niż kiedyś. Jest to jedną z przyczyn pauperyzacji społeczności lokalnych, skupionych jeszcze dwadzieścia - trzydzieści

\footnotetext{
4 F. Kanclerz, Ochrona..., s. 113.

${ }^{5}$ S. Januszewski, Archeologia przemysłowa - jej narodziny i przedmiot badań, http://www.spotkania-z-zabytkami. $\mathrm{pl} /$ artykuly/2/8/1/ - dostęp 11.07.2018.

6 Por. np. Stocznia Meyer Werft - https://www.meyerwerft.de/en/meyerwerft_de/werft/das_unternehmen/ das_unternehmen.jsp - dostęp 11.07.2018.
} 


\section{Nieoczywista rola ruin poprzemysłowych w krajobrazie kulturowym Polski

lat temu wokół jednego wielkiego „chlebodawcy” - huty, kopalni, stoczni itp. I idąc dalej, spowodowało to $\mathrm{w}$ konsekwencji zupełną zmianę sposobu postrzegania roli i charakteru dzisiejszego przemysłu i dzisiejszej roli dawnych obiektów przemysłowych. Generalnie sprowadza się ją do roli „zawalidrogi” w rozwoju przestrzennym miast $-\mathrm{z}$ intencją możliwie szybkiej i całkowitej likwidacji. A gdy na przeszkodzie staje konserwator zabytków, intencja sprowadza się do możliwe największego ograniczenia jego żądań i ingerencji.

Dawne zakłady przemysłowe - huty, kopalnie, stocznie, przędzalnie, etc. zajmowały zwykle znaczne powierzchnie. Niegdyś byly to obrzeża miast, obecnie bardzo często są to ścisłe centra. Z oczywistych względów nadzwyczaj atrakcyjne. Upadek zakładów, pozbawienie gospodarza, popadanie w ruinę (bardzo często były to świadome działania - np. podpalenia) „uwalniały” w części tereny poprzemysłowe. Ich atrakcyjność lokalizacyjna natychmiast generowała presję inwestycyjną. Presję na zaniechanie lub maksymalne złagodzenie ochrony konserwatorskiej, presję na dogodne zapisy $\mathrm{w}$ miejscowych planach zagospodarowania przestrzennego lub presję na przeciąganie w czasie procedur planistycznych i wykorzystywanie „wygodniejszych" uzgodnień warunków zabudowy.

Istotną przeszkodą dla skutecznej ochrony dziedzictwa przemysłowego jest niestety niska społeczna świadomość wartości kulturowych obiektów przemysłowych, na co nakłada się wciąż bardzo słaba edukacja.

Ale obowiązek ochrony i po części opieki na dziedzictwem przemysłu należy do służb konserwatorskich, w których z tą świadomością wartości kulturowych obiektów przemysłowych jest czasami równie mizernie. Przykłady tego stanu rzeczy można znaleźć nawet w wydawanych przezeń decyzjach administracyjnych.

Np. oceniając zasadność ochrony podstacji elektrycznej w Warszawie wzniesionej w 1928 r. konserwator stwierdził, że: [...] wobec ogólnej degradacji technicznej budynków wchodzacych w skład zespołu stacji transformatorowej [...], pozbawienia wyposażenia technicznego oraz wobec ich czysto utylitarnej formy, zabudowa nieruchomości, w swej obecnej postaci, nie odpowiada w petni definicji legalnej zabytku. Jedynym wyróżniajacym się elementem reprezentatywnym dla calego zespotu, $z$ uwagi na zachowany detal architektoniczny, nawiazujacy do form barokowych i klasycystycznych oraz wyważone proporcje jest fasada od strony ul. Mińskiej.

Posiada ona wartość artystyczna i $z$ tego względu obejmuje się ją ochrona konserwatorska poprzez wpis do rejestru zabytków. Jej zachowanie konieczne jest dla udokumentowania formy architektonicznej, jaka była nadawana budynkom municypalnym $w$ okresie dwudziestolecia międzywojennego. Ze względu na ww. powody istotne jest wkomponowanie elewacji frontowych dawnej stacji transformatorowej we wspótczesna tkankę miejskq? . W ten oczywisty sposób działania „konserwatorskie” przyczynią się do zniszczenia jednego z zaledwie czterech tego typu obiektów znajdujących się jeszcze na terenie Warszawy.

\footnotetext{
7 Decyzja Mazowieckiego Wojewódzkiego Konserwatora Zabytków Nr 216/2012 z dnia 13.03.2012 r. w sprawie wpisania zabytku do rejestru zabytków [Elewacje frontowe budynku rozdzielni i budynku warsztatowomagazynowego, wchodzace w skład zespołu zabudowań podstacji elektrycznej, wzniesionej w 1929 r., położonej $w$ Warszawie przy ul. Mińskiej 46].
} 
Rewolucja przemysłowa „kierowała się” nader uniwersalnymi zasadami logistycznymi. Przy lokalizacji zakładów przemysłowych stosowano trzy zasadnicze warunki: dostępność surowców do przetwarzania oraz energii używanej w procesie produkcyjnym, dostępność taniej i w miarę wykwalifikowanej lub podatnej do przyuczenia siły roboczej, dostępność transportu dla dostaw surowca oraz ekspediowania gotowych produktów. Stąd mamy do czynienia ze znaczną koncentracją zakładów reprezentujących jednorodne gałęzie przemysłu na stosunkowo niewielkich obszarach - kopalnie, stocznie, zakłady włókiennicze, itp. Znane są krajobrazy przemysłowe miast Górnego i Dolnego Śląska, Łodzi, Gdańska, Elbląga itp.

Ze względu na „typowość i niewielką „innowacyjność” ówczesnych procesów technologicznych, mamy do czynienia ze sporym podobieństwem w konstrukcji obiektów przemysłowych przeznaczonych dla określonych typów produkcji. Np. podobieństwa budynków przędzalni, hal w hutach, konstrukcji szybów wyciągowych itp. Z jednej strony jest to bardzo interesującym świadectwem swoistej unifikacji budownictwa przemysłowego, $\mathrm{z}$ drugiej bardzo poważnym zagrożeniem w obecnych procesach ochrony konserwatorskiej. Powszechne jest uznawanie obiektów za „mniej ważne” ze względu na to, iż są „typowym przykładem budownictwa przemysłowego".

Ze względu na opisane wyżej przyczyny - szczególnie deindustrializację oraz zmianę charakteru wytwórczości idącą w kierunku „wysokich technologii” - znaczna część dawnych zakładów przemysłowych utraciła na trwale swoje pierwotne funkcje (upadek i bardzo częste „porzucenie” zakładów jako organizmów i budynków jako zaplecza produkcyjnego). Przy tym specyfika konstrukcji dawnych obiektów przemysłowych, wynikająca z określonego charakteru procesów technologicznych, w ogromnym stopniu utrudnia dzisiejszą adaptację do innych funkcji. Szczególną przeszkodą są gabaryty obiektów - np. jednoprzestrzenna hala napraw wagonów w Eisenbahn Hauptewerkstatt Danzig-Troyl (późniejsze ZNTK) w Gdańsku ma rozmiary ok. 205 x $105 \mathrm{~m}$.

\section{Percepcja i tożsamość}

Zapewne każdy w swoich licznych podróżach - i tych prywatnych, i tych zawodowych kierował swoje kroki w stronę ruin zamków, klasztorów, pałaców itp. Fascynują i zachwycają one swoją niesamowitą wręcz malowniczością - własną i swojego położenia w przestrzeni. Fascynują swoistą tajemniczością. Są wręcz naznaczone piętnem dawności.

Zupełnie odmienne w odbiorze są ruiny obiektów poprzemysłowych. Są one uznawane zwyczajnie za brzydkie, ponure, szare, cuchnące smarami itd. Nikomu nie kojarzą się z odległą, tajemniczą historią, bowiem w ich murach pracowali nasi rodzice, dziadkowie, często i my sami. Nie kojarzą się z jakąkolwiek tajemniczością czy romantycznością - przeciwnie są zwyczajne, powszednie, codzienne, nielubiane (wszak spędziliśmy tam my lub nasi ojcowie „pół swojego życia”). Dlatego wyrzucamy je ze swojej pamięci. I dlatego, że nikt nie uznaje ich za wyjątkowe, często cieszymy się, że są niszczone, usuwane, a w ich miejsce powstają najczęściej „szklane domy” galerii handlowych. Czasem „dosłownie” je przykrywając. 


\section{Nieoczywista rola ruin poprzemystowych w krajobrazie kulturowym Polski}

\section{Formy zachowania ruin poprzemysłowych}

$\mathrm{Na}$ tle powyższych rozważań musi pojawić się refleksja - czy w takim razie należy chronić zdegradowane obiekty przemysłowe? Na to pytanie odpowiedź jest oczywista: kryteria estetyczne od dawna nie są już jedyną przesłanką do podjęcia ochrony w stosunku do danej budowli historycznej. Decydować mogą inne wartości kulturowe - takie jak wartość naukowa lub historyczna. W świetle przytoczonych przykładów widać jednak, że w praktyce nawet służby konserwatorskie nie zawsze są $\mathrm{w}$ pełni świadome znaczenia rozwiązań inżynierskich albo technologicznych, które dla dawnego zakładu produkcyjnego są znacznie ważniejsze niż opracowanie architektoniczne elewacji. Jednocześnie nie można zapominać o nieintencjonalnych wartościach estetycznych - między innymi malowniczości - która to cecha jest szczególnie istotna dla przedmiotu niniejszych rozważań - czyli ruin. A zatem jeśli nie ma wątpliwości, czy należy chronić to należy się zastanowić jak to robić. Okazuje się, że wbrew pozorom, nie jest to zjawisko nowe, ani też odosobnione.

\subsection{Metody tradycyjne}

Jednymi z najcenniejszych obiektów przemysłowych będących świadectwem wczesnej industrializacji kraju są pozostałości zakładów produkcyjnych w Staropolskim Okręgu Przemysłowym, m.in. Bobrzy, Nietulisku i Samsonowie i innych miejscowościach Kielecczyzny ${ }^{8}$.

Pierwszy z wymienionych to ruiny zakładu wielkopiecowego budowanego w latach 20. XIX wieku, a którego realizację przerwał wybuch powstania listopadowego. Po jego upadku prac budowlanych nie wznowiono. W istniejących już obiektach umieszczono najpierw produkcję gwoździ, a później przystosowano do potrzeb przemysłu włókienniczego. Co ciekawe, jeszcze w latach 80 . funkcjonowały tutaj zakłady dziewiarskie. Trudno w to uwierzyć patrząc na relikty obiektu, które w szczególny sposób przywodzą na myśl ruiny średniowiecznego zamku: potężny (kilkusetmetrowej długości) mur, wniesienie na którym znajdują się tajemnicze zabudowania malowniczo przenikające się z zielenią, łuki kojarzące się z dawnymi sklepieniami. Pozostałości konstrukcji murowanych zabezpieczone / opracowane zgodnie z tradycyjnymi metodami konserwacji ruin. Jednocześnie pojawiają się (chociaż skromne) elementy informacji co odwiedzający ma przed sobą. Szkoda tylko, że najbliższa makieta ukazująca rekonstrukcję zakładu znajduje się w Narodowym Muzeum Techniki w Warszawie.

Podobna sytuacja ma miejsce w drugiej ze wspomnianych na wstępie miejscowości Samsonowie. Jednak historia tamtejszego obiektu była nieco inna. Huta „Józef” funkcjonowała w latach 1818-1866. Od tego czasu pozostawała w ruinie. Mimo wieloletnich zaniedbań w dziedzinie jej ochrony przed zniszczeniem, w relatywnie dobrym stanie zachowało się znacznie więcej ciągów murów niż Bobrzy ${ }^{9}$. Od pewnego czasu toczy się dyskusja na temat

\footnotetext{
${ }^{8}$ Więcej na ten temat: E. Szot-Radziszewska, Postindustrialne dziedzictwo Staropolskiego Okręgu Przemysłowego w krajobrazie kulturowym Kielecczyzny: zagrożenia i szanse, „Ochrona Zabytków” nr 4: 2009, s. 69-82.

9 A. Czmuchowski, Zabytkowa Huta „Józef” w Samsonowie - potrzeba kompleksowej opieki: sympozjum w Sielpi Wielkiej, 27 lipca 2013 r., „Studia Muzealno-Historyczne” nr 5, 2013, s. 269-272.
} 
udostępnienia turystycznego ruin huty - między innymi proponowana jest budowa wieży widokowej z częściową rekonstrukcją budynku w oparciu o historyczną dokumentację.

Nie są to jedyne w Polsce przypadki zachowania dawnego zakładu przemysłowego $\mathrm{w}$ formie trwałej ruiny. Kolejnym wartym wspomnienia jest dawna fabryka Samuela Abbego na Radogoszczu w Łodzi. W czasie II WŚ pełniła ona funkcję więzienia. W przededniu wyzwolenia miasta Niemcy obiekt spalili wraz ze znajdującymi się w nim ludźmi. Zginęło około 1500 osób. Po tej bestialskiej masakrze obiekt został uznany z Miejsce Pamięci Narodowej. Dramatyczna historia stanowiła przesłankę do zachowania reliktów wielokondygnacyjnego budynku fabryki jako trwałej ruiny będącej pomnikiem tragicznie pomordowanych (proj. architekci Tadeusz Herburt i Wacław Bald, 1961). W drugim etapie, w 1976 roku, dawna hala szedowa została adaptowana dla potrzeb ekspozycji muzealnej, zaś budynek mieszkalny stał się siedzibą pracowni naukowych i administracji. Całość dopełniają znakomite w swoim ekspresyjnym wyrazie elementy rzeźbiarskie oraz metaloplastyczne. Jest to jedyne tego typu działanie w Łodzi, ale nie jedyny obiekt który stał się w mieście ruiną poprzemysłową. Jednak w większości przypadków najbardziej typowe podejście do problemu ruin historycznych - konserwacja zachowawcza oraz ekspozycja reliktów w otoczeniu zieleni - jest nieadekwatne do zurbanizowanej lokalizacji ruin poprzemysłowych.

\section{2. Łódź - laboratorium dziedzictwa przemystowego}

Łódź jako największy w Polsce ośrodek przemysłu włókienniczego od blisko 30 lat mierzy się ze skutkami de-industrializacji. Po 300 niegdyś działających w mieście przedsiębiorstwach zachowało się około 190 zespołów budowlanych, z których znaczna część została przystosowana do nowych potrzeb. Kilka - czasem spektakularnych rozbiórek (czasem o charakterze spontanicznym) nie uszczupliło znacząco zasobu w takim stopniu jak nieudane adaptacje. Gdyż nie w każdym przypadku oznacza to tak wysokiej klasy działania jak w przypadku hotelu Andel's w dawnej przędzalni wysokiej I.K. Poznańskiego, które można uznać za wzorcowe połączenie „starego" i „nowego", czego świadectwem może być choćby uznanie obiektu za Pomnik Historii „Wielokulturowego krajobrazu miasta przemysłowego"10. Wobec znacznej liczby obiektów poddanych transformacji, można zaryzykować stwierdzenie, iż w mieście zaistniały wszystkie problemy związane z ochroną i konserwacją zabytków techniki i przemysłu, a w konsekwencji zastosowano niemal wszystkie dostępne strategie i metody ich rozwiązania.

Charakterystycznym zjawiskiem jest, że praktycznie wszystkie adaptowane w Łodzi obiekty to budynki wielokondygnacyjne. Dużo smutniejszy obraz wyłania się gdy przyjrzeć się parterowym halom szedowym, które ze względu na swoje cechy typologiczne są bardzo trudne do adaptacji, zaś ich lokalizacja zazwyczaj zachęca nowych właścicieli do zwiększenia intensywności zabudowy. Bardzo pouczającym przypadkiem są losy Nowej Tkalni K.W. Scheiblera, położonej u zbiegu ulic Kilińskiego i Tymienieckiego. Był to największy obiekt tego

10 Por.: B.M. Walczak, Krajobraz kulturowy miasta przemysłowego. Prace nad wnioskiem w sprawie uznania wybranych obszarów Łodzi za Pomnik Historii [w:] A. Kępczyńska-Walczak (red.) Zakres i granice ingerencji konserwatorskiej w adaptacji obiektów i zespołów poprzemystowych, Łódź 2012, s. 25-36. 


\section{Nieoczywista rola ruin poprzemystowych $w$ krajobrazie kulturowym Polski

typu w Łodzi - około 4 ha pod jednym dachem. Początkowo (pod koniec lat 90. XX wieku) planowano adaptować ją na supermarket. Ze względów politycznych pozwolenie na budowę zostało wstrzymane w ostatniej chwili przez nowe władze miasta, które wygrały wybory z poparciem lokalnych przedsiębiorców. Od tego czasu budynek zmienia właścicieli i popada w ruinę. Zaledwie kilkanaście lat wystarczyło, żeby zaczął się spontaniczny proces re-naturyzacji, czemu sprzyja położenie w dolinie niewielkiej rzeki.

Bardzo ważnym faktem wpływającym na losy tkalni bez wątpienia byly odwiedziny wtedy jeszcze czynnego zakładu przez papieża Jana Pawła II, który przemawiał tu w 1987 roku do licznie zgromadzonych włókniarek. Z tego powodu halę często nazywa się Tkalnią Papieską. Niestety zly stan obiektu sprawia, że tablicę pamiątkową przeniesiono na inny budynek, co w dalszej perspektywie może wprowadzać w błąd nieświadomych użytkowników.

Biorąc pod uwagę, że obiekt znajduje się w dolinie rzecznej, aż prosiłoby się, żeby zastosować metody, które zostały rozwinięte w Niemczech podczas IBA Emscher Park (19891999) oraz IBA Fürst-Pückler-Land (2000-2010). W obu przypadkach uznano, że obiekty przemysłowe stanowiące ważny element dziedzictwa lokalnego oraz krajobrazu kulturowego regionu należy zachować jako swoiste rzeźby, instalacje artystyczne, albo po prostu trwałe ruiny w ramach nowo założonych terenów rekreacyjnych.

W kontekście rozważań dotyczących problemu ruin poprzemysłowych bardzo ważnym przypadkiem jest dawna fabryka R. Biedermanna przy ul. Smugowej w Łodzi.

W połowie lat 90. XX wieku zakład - jak wiele innych w Łodzi - był jeszcze w ruchu. Dziesięć lat później już wyłączony z eksploatacji i sprzedany prywatnym właścicielom spłonął. Następne kilka lat upływało na nieudanych negocjacjach między WKZ a właścicielami co do zakresu ochrony (obiekt figurował w ewidencji) oraz możliwości jego przekształceń. Po ich fiasku na teren wjechały buldożery, a jedyne co mógł wtedy zrobić konserwator to wstrzymać prace na podstawie wszczęcia procedury wpisu do rejestru. W rezultacie „interwencyjnie” udało się objąć ochroną to co jeszcze z zakładu zostało - czyli de facto ruinę. Nie wiadomo jak to w rzeczywistości wpłynie na dalsze losy zakładu, ale miejsce stało się inspirujące dla studentów architektury, którzy chętnie mierzą się z tematem zagospodarowania terenu ruiny poprzemysłowej.

Zazwyczaj jednak obiekty przemysłowe były w Łodzi poddawane mniej lub bardziej udanym pracom adaptacyjno-konserwatorskim. Zdarzało się to nawet w przypadkach, gdy stan budynku trudno opisać inaczej niż ruina. Decydowała o tym swoista „moda na industrial”, która zapanowała w mieście po 2006 roku, kiedy oddano do użytku centrum Manufaktura w dawnych zakładach I.K. Poznańskiego.

Jednym z przykładów może być siedziba zarządu Łódzkiej Specjalnej Strefy Ekonomicznej w murach dawnej fabryki L. Grohmana. Teren przedsiębiorstwa został przekazany ŁSSE jeszcze w latach 90. XX wieku, kiedy nikt $z$ decydentów jeszcze nie wyobrażał sobie, że zakład produkcyjny może pełnić inną funkcjęniż przemysłowa. Co więcej, w realiach kryzysu społecznogospodarczego priorytetem było utworzenie nowych miejsc pracy nawet kosztem historycznej zabudowy przemysłowej. W rezultacie jest to teren, który stał się ilustracją ewolucji postaw 
wobec lokalnej spuścizny poprzemysłowej - od negacji, poprzez racjonalne wykorzystanie, aż po afirmację. Kierując się tym ostatnim nastawieniem, zarząd ŁSSE SA postanowił przenieść swoją siedzibę do zespołu budynków obejmującego kotłownię, maszynownię i wieżę wodną. Jednak stan obiektów był na tyle zły, że zachowano jedynie mury obwodowe, co skłoniło projektantów do dodania kolejnej „warstwy”, która nie tylko miała odzwierciedlać współczesność, ale także scalić kompozycyjnie rozczłonkowany i silnie zdegradowany budynek. Tym samym relikty przemysłowej zabudowy stały się inspiracją do krytycznej kreacji architektonicznej.

Jeszcze dalej posunęli się właściciele centrum handlowego Sukcesja przy al. Politechniki. Dawna fabryka Gampe i Albrecht najpierw została całkowicie wyburzona, a następnie na fali rosnącego zainteresowania dziedzictwem poprzemysłowym „odbudowana” w innej formie i lokalizacji. Jedna z elewacji nowego obiektu została ukształtowana jak fasada typowej łódzkiej fabryki z przełomu XIX i XX wieku. Całość tchnie niestety sztucznością i mimo starań o dobrą jakość wykonawstwa, może być postrzegane jedynie jako próba uzyskania wymiernych korzyści biznesowych w oparciu o nastroje społeczne. Inwestorom ponownie zabrakło wyczucia gdyż w kraju i zagranicą istnieje wiele pozytywnych przykładów kształtowania współczesnej architektury, będącej postindustrialną stylizacją (np. Stary Browar w Poznaniu) ${ }^{11}$.

\subsection{Inne zagadnienia zwiazane z poprzemystowymi reliktami}

Wyżej wymienione przykłady odnoszą się do sytuacji, gdy obiekt przemysłowy stał się przedmiotem zainteresowania po dłuższym okresie nieużytkowania, które doprowadziło do znacznej degradacji jego stanu technicznego. Utrzymanie stanu ruiny było jedną z możliwości i w wyjątkowych przypadkach jest traktowane jako stan docelowy. Jest jednak duża grupa obiektów, które nie kwalifikują się do adaptacji ze względu na swoje pierwotne przeznaczenie. Najlepszymi i najczęściej spotykanymi przykładami są kominy, nadszybia kopalni i wieże ciśnień. Jednak stanowią one ważny składnik krajobrazu kulturowego. Dlatego za ich zachowaniem oraz ochroną przemawia rola symboli industrializacji i znaków przestrzennych. Dobrą ilustracją wymiernej wartości tego typu reliktów poprzemysłowych może być sylweta dawnej Kopalni Katowice - dziś Muzeum Śląskiego - która została zastrzeżona jako znak towarowy, aby uniknąć swobodnego jej wykorzystywania jako „podbudowy” różnych przedsięwzięć biznesowych oraz promocyjnych.

Zachowanie wybranych fragmentów obiektów przemysłowych przeznaczonych do rozbiórki potraktowano jako strategię utrwalania pamięci o industrialnym rodowodzie wielu miast europejskich - m.in. Terrassy w Katalonii. Stają się one swoistymi rzeźbami w przestrzeni miasta, lub też zostają wkomponowane w nową zabudowę, na przykład jako zadaszenie głównego wejścia. Stosuje się również zabiegi takie jak lapidaria (np. Delmenhorst koło Bremy w Niemczech) a nawet symboliczne upamiętnienie w formie pomnika (np. Catrine w Szkocji).

${ }_{11}$ A. Kępczyńska-Walczak, Industrial Heritage Revitalisation as a Wordplay [w:] A. Kepczyńska-Walczak (red.) Envisioning Architecture. Image, Perception and Communication of Heritage, Łódź 2015, s. 39-48 
Nieoczywista rola ruin poprzemystowych w krajobrazie kulturowym Polski

\section{Podsumowanie i wnioski}

Z powyższego przeglądu wynika, że zastosowanie tradycyjnej metodologii ochrony ruin historycznych jest $\mathrm{w}$ pewnych przypadkach możliwe do zastosowania. Jednak większość dawnych obiektów przemysłowych zachowała się nie w otwartym krajobrazie lecz na obszarach zurbanizowanych. Silna presja ze strony rynku nieruchomości sprawia, że trudno jest promować rozwiązania ekstensywne. Nawet silnie zdegradowane obiekty stają się przedmiotem zainteresowania inwestorów. Warto propagować wkomponowanie reliktów w nowe zagospodarowanie nieruchomości, aby podkreślić jej przemysłowy rodowód.

Szczęśliwie daje się zauważyć narastająca fascynacja obiektami poprzemysłowymi, "modnie” określanymi mianem postindustrialnymi. Dowodzą tego m.in. fora internetowe, blogi i portale, gdzie autorzy zamieszczają liczne (często bardzo dobre) fotografie opuszczonych i zrujnowanych obiektów. Wyszukują i zamieszczają informacje o dziejach dawnych i najnowszych eksplorowanych przez siebie obiektów, o ich pierwotnej funkcji, wyszukują podobne obiekty w swojej bliższej lub dalszej okolicy.

Można zaryzykować stwierdzenie, że jest to zjawisko podobne do zainteresowania ruinami w ich szczególnej odmianie jako miejsca owianego tajemniczością i grozą, które na przełomie XVIII i XIX w. rozwinęło się na fali romantyzmu w kulturze. Jego przejawem w architekturze było upodobanie dla gotyku, którego prekursorem był angielski arystokrata Horacy Walpole - właściciel rezydencji Strawberry Hill, pierwszej neogotyckiej budowli w Europie, a przede wszystkim pisarz, który w 1764 roku opublikował Zamczysko w Otranto pierwszą "gotycką" powieść. Literatura tego typu spotkała się z żywym zainteresowaniem i szybko przeniknęła do ówczesnej kultury masowej, czego najlepszym przykładem może być Frankenstein, czyli współczesny Prometeusz autorstwa Mary Shelly. Ale nawet literatura romantyczna głównego nurtu skłaniała czytelników do refleksji i zadumy, co bez wątpienia miało wpływ na stosunek do ruin zamków, które stały się jednym $\mathrm{z}$ najwcześniejszych przedmiotów zainteresowania z pozycji konserwatorskich.

„Gotyckość” jest nadal obecna we współczesnej kulturze. Może mieć ona swój wymiar subkulturowy (związany głównie $\mathrm{z}$ muzyką) w który ruiny poprzemysłowe są wpisane niezwykle silnie. Nieprzypadkowo Jim Jarmusch na miejsce akcji filmu Tylko kochankowie przeżyją, opowiadającego współczesne losy wampirów, wybrał upadające Detroit. Natomiast $\mathrm{w}$ wymiarze popularnym otoczenie industrialne po prostu silnie przemawia do młodszego pokolenia, dla którego chylące się ku ruinie fabryki są źródłem równie silnych przeżyć, jak średniowieczne zamczyska do ich pradziadów. Jednak ruiny zamków w większości przypadków w wyniku wieloletnich prac konserwatorskich zostały w pewien sposób „oswojone”. Co więcej, we współczesnym świecie zabytki zmuszone są konkurować z atrakcjami świata cyfrowego. Oznacza to, że dla coraz większej części społeczeństwa ma znaczenie przede wszystkim autentyzm przeżyć1 ${ }^{12}$. Świadczyć może o tym renesans „flaneryzmu” w nowej post-industrialnej

12 por. G.J. Ashworth, Can you move from the object to the experience? [w:] Kongres Konserwatorów Polskich, Warszawa 2005. 


\section{2 \\ Jacek Dąbrowski, Bartosz M. Walczak}

odsłonie, odnotowany przez Tima Edensora ${ }^{13}$.

Możemy jedynie życzyć sobie aby takie samo zainteresowanie obiekty poprzemysłowe, lub ich ruiny, budziły u stosownych władz - zarówno samorządowych, jak i konserwatorskich. 